\title{
Yew and juniper pollen season in selected cities of Poland in 2020
}

\author{
Katarzyna Dąbrowska-Zapart', Kazimiera Chłopek ${ }^{1}$, Małgorzata Puc ${ }^{2}$, Małgorzata Malkiewicz ${ }^{3}$, Agata Konarska ${ }^{4}$, \\ Anna Rapiejk0 ${ }^{5}$, Kornel Szczygielski ${ }^{6}$, Monika Ziemianin ${ }^{7}$, Grzegorz Siergiejko ${ }^{8}$, Agnieszka Lipiec ${ }^{9}$ \\ ${ }^{1}$ Faculty of Natural Sciences, Institute of Earth Sciences, University of Silesia, Poland \\ ${ }^{2}$ Institute of Marine \& Environmental Sciences, University of Szczecin, Poland \\ ${ }^{3}$ Laboratory of Paleobotany, Department of Stratigraphic Geology, Institute of Geological Sciences, \\ University of Wroclaw, Poland \\ ${ }^{4}$ Department of Botany and Plant Physiology, University of Life Sciences in Lublin, Poland \\ ${ }^{5}$ Allergen Research Center, Warsaw, Poland \\ ${ }^{6}$ Department of Otolaryngology with Division of Cranio-Maxillo-Facial Surgery, Military Institute of Medicine, \\ Warsaw, Poland \\ ${ }^{7}$ Department of Clinical and Environmental Allergology, Medical College, Jagiellonian University, Cracow, Poland \\ ${ }^{8}$ Pediatrics, Gastroenterology and Allergology Department, University Children Hospital, Medical University of \\ Bialystok, Poland \\ ${ }^{9}$ Department of Prevention of Environmental Hazards and Allergology, Medical University of Warsaw, Poland
}

\begin{abstract}
:
The study compares the yew and juniper pollen seasons in Bialystok, Bydgoszcz, Cracow, Lublin, Piotrkow Trybunalski, Sosnowiec, Szczecin, Warsaw, and Wroclaw in 2020. The investigations were conducted using the volumetric method. The yew and juniper season started in all measurement sites between February $2^{\text {nd }}$ (Szczecin) and March $2^{\text {nd }}$ (Lublin). The peak values of seasonal pollen count occurred between February 23 $3^{\text {rd }}$ (in Szczecin) and March 28 $8^{\text {th }}$. The highest daily pollen count was recorded in Lublin $\left(867 \mathrm{grains} / \mathrm{m}^{3}\right)$ and the lowest pollen count in Bialystok $\left(45 \mathrm{grains} / \mathrm{m}^{3}\right)$. The highest annual totals were recorded in Lublin and Wroclaw. Most days, with a concentration equal to or above $50 \mathrm{grains} / \mathrm{m}^{3}$, causing symptoms in allergic patients were recorded in Lublin and Warsaw.
\end{abstract}

Key words: allergens, pollen count, yew (Taxus baccata), juniper (Juniperus sp.), Poland, 2020

\section{Introduction}

Next to hazel and alder pollen, the yew pollen is one of the first to appear in the atmosphere in early spring [1]. In nature, yew is relatively rare in Poland, but it is often planted in parks and gardens. Small, non-deceptive inflorescences and an early yew pollen season may be a potential cause of allergic symptoms that are difficult to diagnose. Yew pollen grains are difficult to distinguish from juniper pollen grains under standard light microscopy; therefore, the authors decided to present the results of the concentrations of these two taxa collectively. Yew blooms earlier than juniper. Therefore, based on phenological observations, it is possible to approximate the early phase of the yew/ juniper season, dominated by yew, and the late phase, dominated by juniper. Juniper pollen allergens are a documented cause of allergic diseases in Southern Europe and Asia [1-10]. However, the threshold concentration of yew and juniper pollen at which allergic symptoms are observed in people with hypersensitivity is not clearly established [1]. Yew and juniper are characterized by variable habits, including shrubs and trees, often grown in parks, gardens, and urban tree stands. Their common presence in our environment is associated with pollen's abundant air presence during their flowering and pollination [11-13]. Therefore, although yew and juniper pollen allergens' clinical significance has not been fully explained, the prevention of pollen allergy requires studies of the pollen concentration of these plants in the following years, especially that the 
intensity of allergy symptoms to the yew and juniper pollen antigens is also local [11-13].

Aim

The aim of the study was to compare the yew and juniper pollen season in Bialystok, Bydgoszcz, Cracow, Lublin, Piotrkow Trybunalski, Sosnowiec, Szczecin, Warsaw, and Wroclaw in 2020.

\section{Material and method}

The analysis of yew and juniper pollen concentration in the air of selected Polish cities was conducted based on data from 2020. Both taxis were treated together because their grains are similar, also concerning their allergenic properties. Pollen concentration measurements were carried out with the volumetric method using Burkard and Lanzoni 2000 [14]. The duration of the pollen season was determined by the 98\% method. The total pollen count over this period was expressed by the SPI (seasonal pollen index). The course of the pollen seasons in each city is shown in the graphs (fig. 1-4).

The number of days with concentrations of yew and juniper pollen exceeding the threshold value at which disease symptoms are observed in hypersensitive individuals was determined based on literature.
The studies conducted by Waisel et al. [15] showed that the threshold concentration of Cupressaceae pollen is $50-60$ grains $/ \mathrm{m}^{3}$.

\section{Results and discussion}

In Poland, the periods of pollination of yew and juniper usually coincide in March because the pollination of yew is observed mainly in February and March, while juniper pollination mainly in March and April. Due to the morphological similarity of pollen grains of both taxa, the pollen seasons of yew and juniper are considered together.

In Szczecin, the earliest beginning of the pollen season, which started already on February $2^{\text {nd }}, 20$ days earlier than in 2019, was found [16]. In general, the pollen season of yew and juniper began in all cities earlier than a year ago (tab. 1) [16]. The smallest difference in the beginning dates of the pollen season between 2019 and 2020 was recorded for Lublin - it was only 3 days.

In Szczecin and Bialystok, the pollen season lasted a very long time and amounted to 120 and 110 days, respectively (tab. 1). The shortest season was observed in Wroclaw and was only 30 days (fig. 4).

The high concentration of yew and juniper pollen grains was recorded in Szczecin and Wroclaw already in the second decade of February (fig. 3, 4).

Table 1. Characteristics of yew and juniper pollen season in 2020.

\begin{tabular}{|c|c|c|c|c|c|}
\hline Site & $\begin{array}{l}\text { Duration of pollen } \\
\text { season (number and days) }\end{array}$ & $\begin{array}{c}\left.\text { Peak value [grains } / \mathrm{m}^{3}\right] \\
\text { and peak date }\end{array}$ & $\begin{array}{l}\text { Seasonal pollen } \\
\text { index (SPI) }\end{array}$ & Days $\geq 50$ grains $/ \mathrm{m}^{3}$ & Days $\geq 100$ grains $/ \mathrm{m}^{3}$ \\
\hline Bialystok & $\begin{array}{c}11.02-30.05 \\
110\end{array}$ & $\begin{array}{c}45 \\
12.03\end{array}$ & 361 & 0 & 0 \\
\hline Bydgoszcz & $\begin{array}{c}7.02-22.05 \\
106\end{array}$ & $\begin{array}{c}177 \\
11.03\end{array}$ & 1119 & 3 & 2 \\
\hline Cracow & $\begin{array}{c}23.02-9.04 \\
47\end{array}$ & $\begin{array}{l}310 \\
1.03\end{array}$ & 1714 & 8 & 5 \\
\hline Lublin & $\begin{array}{c}2.03-11.05 \\
71\end{array}$ & $\begin{array}{c}867 \\
28.03\end{array}$ & 5407 & 23 & 13 \\
\hline Sosnowiec & $\begin{array}{l}17.02-20.05 \\
94\end{array}$ & $\begin{array}{c}127 \\
10.03\end{array}$ & 1052 & 4 & 1 \\
\hline $\begin{array}{l}\text { Piotrkow } \\
\text { Trybunalski }\end{array}$ & $\begin{array}{l}17.02-16.05 \\
90\end{array}$ & $\begin{array}{c}243 \\
10.03\end{array}$ & 1802 & 9 & 3 \\
\hline Szczecin & $\begin{array}{l}2.02-31.05 \\
120\end{array}$ & $\begin{array}{c}181 \\
23.02\end{array}$ & 1339 & 8 & 3 \\
\hline Warsaw & $\begin{array}{c}17.02-13.05 \\
87\end{array}$ & $\begin{array}{c}178 \\
10.03\end{array}$ & 1832 & 11 & 4 \\
\hline Wroclaw & $\begin{array}{c}16.02-16.03 \\
30\end{array}$ & $\begin{array}{l}723 \\
1.03\end{array}$ & 2205 & 9 & 5 \\
\hline
\end{tabular}


Figure 1. Yew and juniper pollen count in Bialystok and Bydgoszcz in 2020.

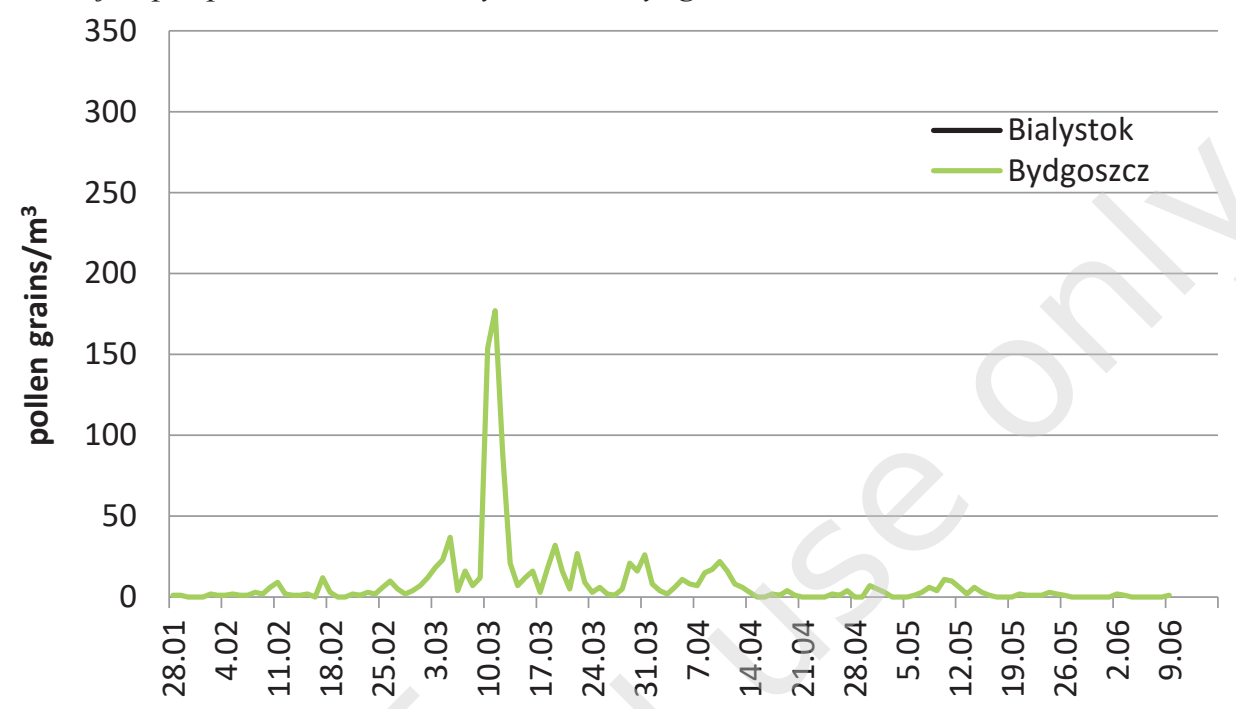

Figure 2. Yew and juniper pollen count in Cracow and Lublin in 2020.

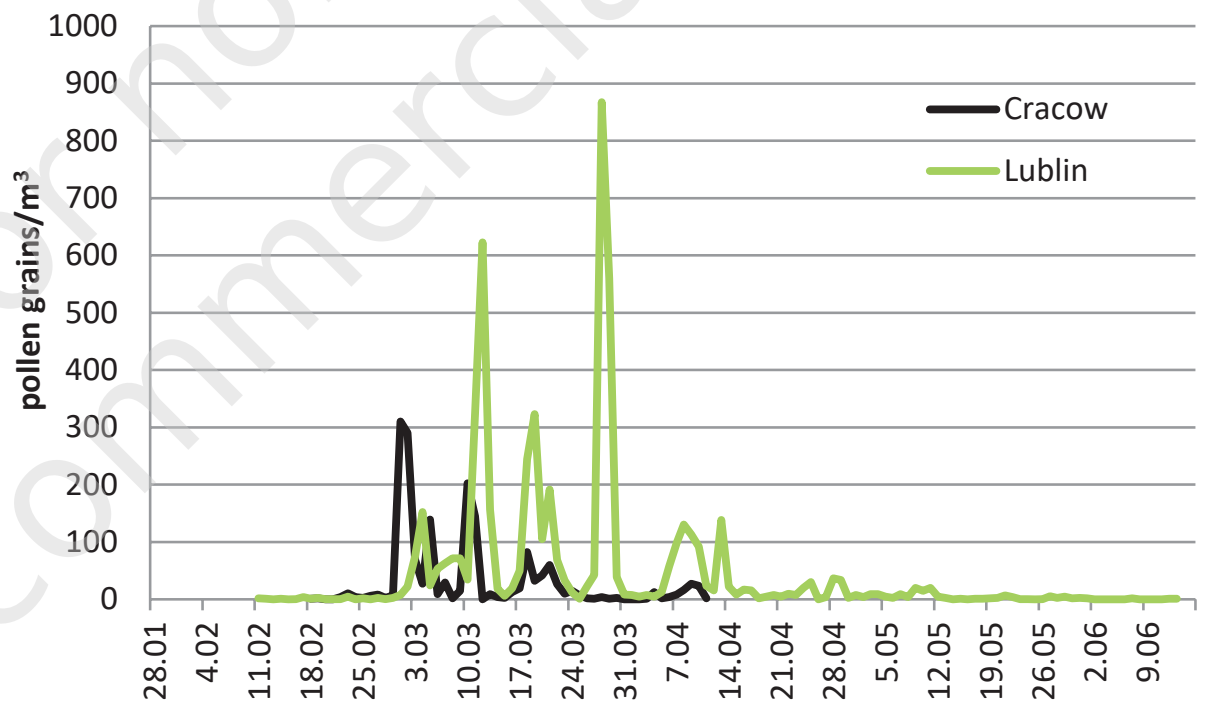

Figure 3. Yew and juniper pollen count in Piotrkow Trybunalski, Sosnowiec and Szczecin in 2020.

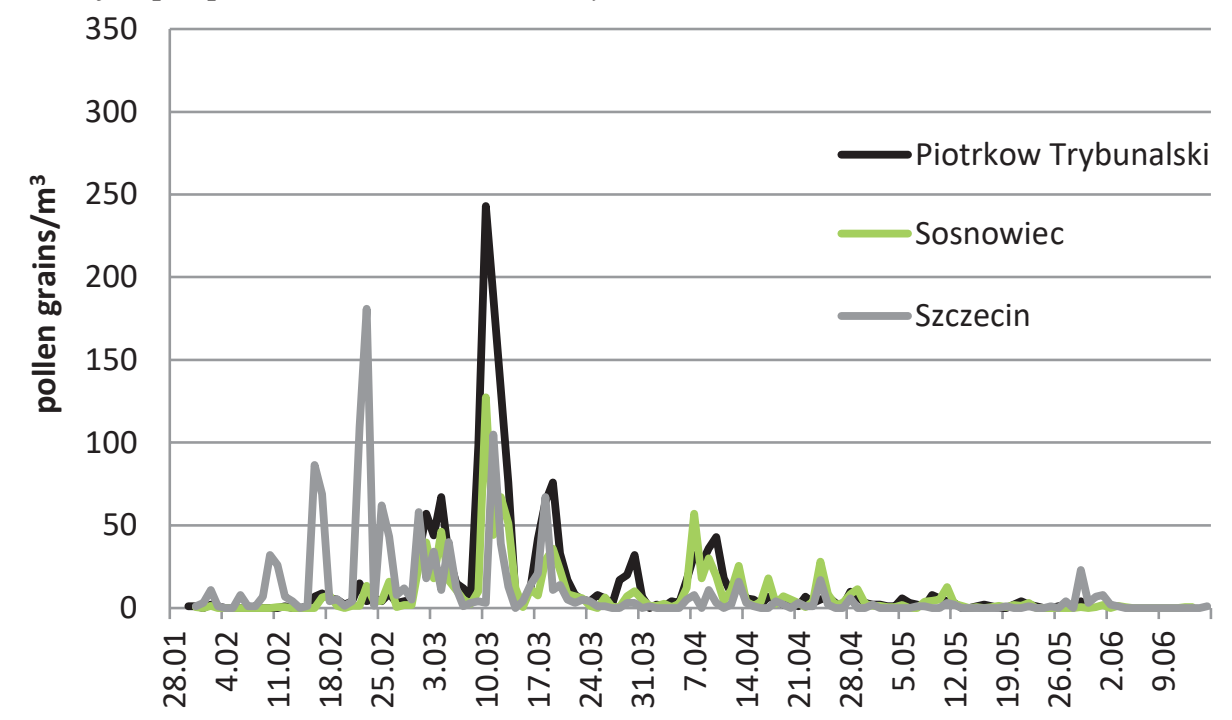


Figure 4. Yew and juniper pollen count in Warsaw and Wroclaw in 2020.

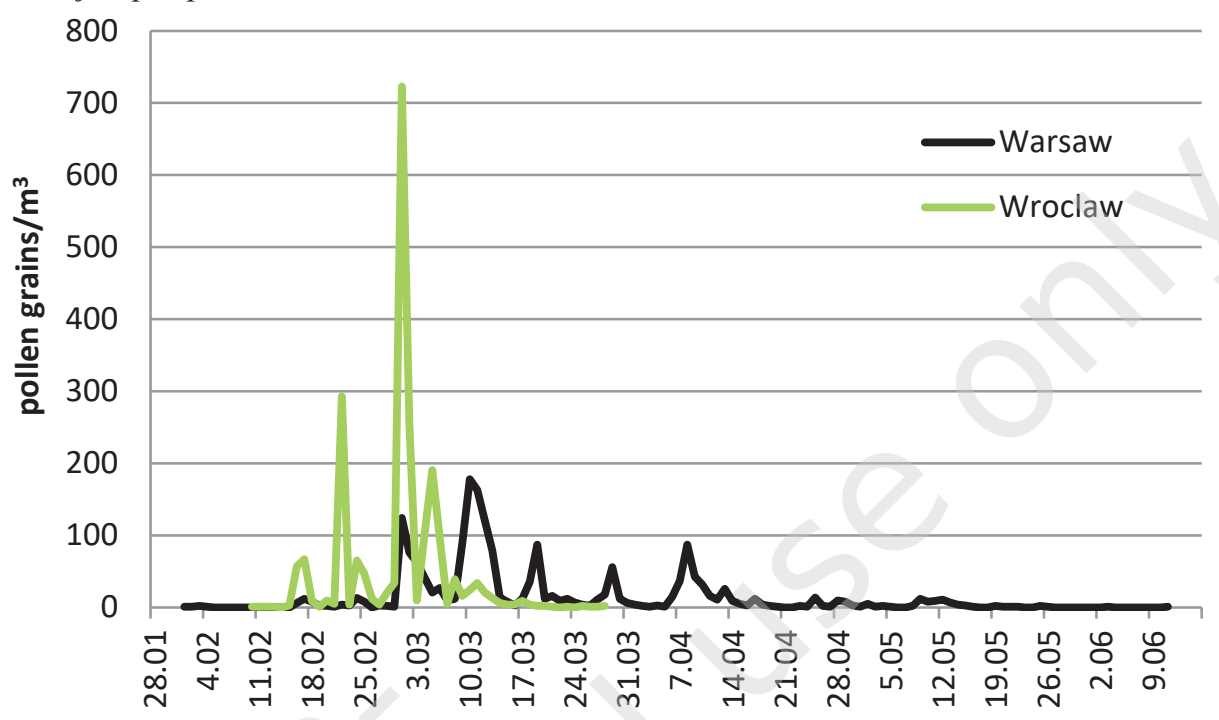

The highest daily pollen count was recorded in Lublin 867 grains $/ \mathrm{m}^{3}$ and Wroclaw - 723 grains $/ \mathrm{m}^{3}$ (fig. 2, 4). While the lowest concentration of pollen was found in Bialystok - it was only 45 grains $/ \mathrm{m}^{3}$ (fig. 1). Maximum of pollen concentrations were detected in the $1^{\text {st }}$ and $2^{\text {nd }}$ decade of March in all analyzed cities, except for Szczecin. The peak with the maximum daily concentration occurred there on February $23^{\text {rd }}$ (tab. 1).

In 2020, the sums of yew and juniper pollen grains were in the range of 361-5407; the highest sum of grains was noted in Lublin (5407), and Wroclaw (2205), and the lowest totals were recorded in Bialystok (361) (tab. 1).

The highest yew and juniper pollen risk (above 50 grains $/ \mathrm{m}^{3}$ ) occurred in Lublin (23 days) and Warsaw (11 days) (tab. 1). In other cities, this value was 0-9 days (tab. 1).

\section{Conclusions}

1. The pollen season of yew and juniper in 2020 began in Szczecin at the earliest, because as early as February $2^{\text {nd }}$, while the latest pollen season was observed in Lublin (March $2^{\text {nd }}$ ).

2. The highest concentrations of yew and juniper pollen were recorded in Lublin and Wroclaw, whereas the lowest concentrations were noted for Bialystok.

3. The highest pollen allergen risk occurred in Lublin and Warsaw.

\section{References}

1. Rapiejko P. Pytek roślin. In: Zawisza E, Samoliński B (ed). Choroby alergiczne. PZWL, Warszawa 1998: 328-54.

2. Andre C, Dumur JP, Hrabina $M$ et al. Juniperus ashei: the gold standard of the Cuppressaceae. Allerg Immunol (Paris). 2000; 32(3): 104-6.

3. Czerwinski EW, Midoro-Horiuti T, White MA et al. Crystal structure of Jun a 1, the major cedar pollen allergen from Juniperus ashei, reveals a parallel beta-helical core. J Biol Chem. 2005; 280(5): 3740-6.

4. Hrabina M, Dumur JP, Sicard H et al. Diagnosis of cypress pollen allergy: in vivo and in vitro standardization of a Juniperus ashei pollen extract. Allergy. 2003; 58(8): 808-13.

5. Kimura Y, Kamamoto M, Maeda M et al. Occurrence of Lewis a epitope in $\mathrm{N}$-glycans of a glycoallergen, Jun a 1, from mountain cedar (Juniperus ashei) pollen. Biosci Biotechnol Biochem. 2005; 69(1): 137-44.

6. Maguchi S, Fukuda S. Taxus cuspidata (Japanese yew) pollen nasal allergy. Auris Nasus Larynx. 2001; 28 suppl: S43-7.

7. Midoro-Horiuti T, Nouno S, Seino Y. Skin tests of pollen grains of taxodiaceae and cupressaceae in children with bronchial asthma. Acta Paediatr Jpn. 1992; 34(5): 501-4.

8. Panzani R, Yasueda H, Shimizu T et al. Cross-reactivity between the pollens of Cupressus sempervirens (common cypress) and of Cryptomeria japonica (Japanese cedar). Ann Allergy. 1986; 57(1): 26-30.

9. Vanhaelen M, Duchateau J, Vanhaelen-Fastre R et al. Taxanes in Taxus baccata pollen: cardiotoxicity and/or allergenicity? Planta Med. 2002; 68(1): 36-40.

10. Vervloet D, Birnbaum J, Laurent $P$ et al. Safety and efficacy of Juniperus ashei sublingual-swallowultra-rush pollen immunotherapy in cypress rhinoconjunctivitis. A double-blind, placebo-controlled study. Int Arch Allergy Immunol. 2007; 142(3): 239-46. 
11. Lorenzoni-Chiesura F, Giorato M, Marcer G. Allergy to pollen of urban cultivated plants. Aerobiologia. 2000; 16: 313-6.

12. Norris-Hill J, Emberlin J. Diurnal variation of pollen concentration in the air of north-central London. Grana. 1991; 30: 229-34.

13. Puc M, Weryszko-Chmielewska E. Analiza stężenia ziaren pytku Taxus baccata i Juniperus sp. w powietrzu Szczecina i Lublina w 2000 r. Monitor Pytkowy. 2002; 7: 3-7.

14. Mandrioli P, Comtois P, Dominguez E et al. Sampling: Principles and Techniques. In: Methods in Aerobiology. Mandrioli P, Comtois P, Levizzani V (ed). Pitagora Editrice Bologna, Bologna 1998: 47-112.

15. Waisel Y, Mienis Z, Kosman E et al. The partial contribution of specific airborne pollen to pollen induced allergy. Aerobiologia. 2004; 20(3): 197-208.

16. Puc M, Kotrych D, Malkiewicz M et. al. Yew and juniper pollen season in the air of Poland in 2019. Alergoprofil. 2019; 15(2): 3-8.

ORCID

K. Dąbrowska-Zapart - ID - orcid.org/0000-0002-8976-7739

M. Puc - ID - orcid.org/0000-0001-6734-9352

M. Malkiewicz - ID - orcid.org/0000-0001-6768-7968

A. Konarska - ID - orcid.org/ 0000-0003-2174-7608
A. Rapiejko - ID - orcid.org/0000-0002-8906-2405

K. Szczygielski - ID - orcid.org/0000-0002-3717-5424

M. Ziemianin - ID - orcid.org/0000-0003-4568-8710

G. Siergiejko - ID - orcid.org/0000-0003-4084-8332

A. Lipiec - ID - orcid.org/0000-0003-3037-2326

Authors' contributions:

K. Dąbrowska-Zapart: 50\%; K. Chłopek: 10\%; other Authors: 5\% each.

Conflict of interests:

The authors declare that they have no competing interests.

Financial support: Does not occur.

Ethics: The contents presented in this paper are compatible with the rules the Declaration of Helsinki, EU directives and standardized requirements for medical journals.

Research in Bialystok, Bydgoszcz, Cracow, Lublin, Piotrkow Trybunalski, Sosnowiec, Szczecin, Warsaw, Wroclaw funded by Allergen Research Center Ltd. (Ośrodek Badania Alergenów Środowiskowych Sp. z 0.0.)

Copyright: (C) Medical Education sp. z 0.0. This is an Open Access article distributed under the terms of the Attribution-NonCommercial 4.0 International (CC BY-NC 4.0). License (https://creativecommons.org/licenses/by-nc/4.0/), allowing third parties to copy and redistribute the material in any medium or format and to remix, transform, and build upon the material, provided the original work is properly cited and states its license.

\section{Correspondence}

\section{Katarzyna Dąbrowska-Zapart, PhD}

Faculty of Natural Sciences, Institute of Earth Sciences, University of Silesia, Poland

41-200 Sosnowiec, Będzińska 60

tel. (032) 3689477

e-mail: katarzyna.dabrowska-zapart@us.edu.pl 